\title{
EXCLUSION, TRANSITION, AND RECOGNITION: NORMATIVE ARCHETYPES FOR CROSSING URBAN SOCIAL SPACES ${ }^{1}$
}

\author{
Alberto Pirni (a) \\ (a) Sant'Anna School of Advanced Studies. Piazza Martiri della Libertà, 33, 56127 Pisa PI, Italy. \\ Email: alberto.pirni[at]santannapisa.it
}

\begin{abstract}
The paper intends to explore three archetypes of possible interaction between the agent and the social space in which one's own action is located. In this article, we will talk about modalities endowed with normative significance, that is focused around universal scopes and extra-contextual validities (values). Special attention will be paid to the dimension of the "intersection of social spaces" (the scheme assumes both the permanent dimension of "acting within spaces" and the dynamic dimension of "passing beyond them"), the modalities of exclusion, transition, and recognition are thus presented. Their action is complicated by alternative intersection paths in introdynamic and extradynamic dimensions. The study proposes to represent these modalities in order to further offer scenarios for the development and change of urban social spaces.

Finally, the paper intends to propose a phenomenological interpretation of their possible interaction with reference to some ways of transforming urban spaces, which are typical of the European context.
\end{abstract}

\section{Keywords}

Urban spaces; urban communities; urban planning; urban philosophical anthropology; extra-contextual validities; exclusion; transition; recognition; intersection; transforming urban spaces

This work is licensed under a Creative Commons «Attribution» 4.0 International License.

\footnotetext{
${ }^{1}$ The reported study was funded by RFBR according to the research project № 18-011-00552 at SPSU.
} 


\title{
ОТЧУЖДЕНИЕ, ТРАНЗИТИВНОСТЬ И ПРИЗНАНИЕ: НОРМАТИВНЫЕ АРХЕТИПЫ ДЛЯ ПЕРЕСЕЧЕНИЯ ГОРОДСКИХ СОЦИАЛЬНЫХ ПРОСТРАНСТВ ${ }^{1}$
}

\author{
Пирни Альберто (а)
}

(а) Школа перспективных исследований имени Святой Анны. Piazza Martiri della Libertà, 33, 6127 Pisa PI. Италия. E-mail: alberto.pirni[at]santannapisa.it

\section{Аннотация}

Данная статья направлена на исследование трех архетипов возможного взаимодействия субъекта с социальным пространством, в котором происходит действие. В статье рассматриваются модальности, наделенные нормативным значением, т.е. сфокусированным вокруг универсальных сфер действий и внеконтекстуальных валидаций (ценностей). Особое внимание уделяется измерению «пересечения социальных пространств» (схема предполагает как перманентное «действие в пространствах», так и динамический «выход за их пределы»), таким образом, представлены модусы исключения, перехода и признания. Их действие осложняется существованием альтернативных путей пересечения в интродинамическом и экстрадинамическом измерениях. В исследовании предлагается представить эти модальности, чтобы в дальнейшем предложить сценарии развития и изменения городских социальных пространств.

Наконец, в работе предлагается феноменологическая интерпретация их возможного взаимодействия применительно к некоторым способам трансформации городских пространств в европейском контексте.

\section{Ключевые слова}

Городское пространство; городские общины; городское планирование; городская философская антропология; внеконтекстуальные обоснования; отчуждение; транзитивность; признание; пересечение; трансформация городского пространства.

Это произведение доступно по лицензии Creative Commons «Attribution» («Атрибуция») 4.0 Всемирная.

\footnotetext{
${ }^{1}$ Исследование выполнено при финансовой поддержке РФФИ в рамках научного проекта № 18011-00552 в СПбГУ.
} 


\section{PREMISE-PRELIMINARY LINES FOR AN URBAN PHILOSOPHICAL ANTHROPOLOGY}

The paper tres to present a specific part of the research agenda I've been conducting in Pisa over the past few years and which is still on the way ${ }^{1}$. The focal point could be summarized in the formula which I used in my last book: the challenge of living together (Pirni, 2018b). What I'm going to present in this context is an attempt to develop some correlative issues linked to the same main core, namely, issues related to the contexts in which that challenge might take place, having in mind - firstly, but not exclusively - the urban contexts ${ }^{2}$.

I would like to introduce the argumentative path as follows. First, I shall offer a preliminary account about what I'm calling "urban philosophical anthropology". Then, I will present a theoretical path related to the topic that takes advantage from addressing two methodological issues. The first one concerns the correlative concepts of identity and the otherness in the urban context. The second issue requires a more precise, namely a more specific definition of what is the "intersection of social spaces". Accordingly, we will talk about what I call "normative archetypes" that connotates the very idea of the "crossing urban spaces", by presenting three of such archetypes (by recalling the Weberian use of the word): Exclusion, transition and recognition. Finally, I'm going to propose a comprehensive interpretation of the interplay among them, within a phenomenological point of view.

What is meant when we talk about what we might call a "urban philosophical anthropology"? I would like to introduce this concept as a sort of methodological tool finalized to a better understanding of our contemporary urban daily life.

When we talk about urban philosophical anthropology we are alluding to a context in which an agent has to deal with an urban social space, whatever we stipulatively decide to define it. The simplest and the phenomenologically reduced situation contemplates two concepts: the concept of agent - a person who can spend time in a specific space, by performing certain actions, and, correlatively, the concept of a context that gathers such actions, namely, the urban social space itself. The agent is an

\footnotetext{
1 This essay reproduces the oral talk delivered with the same title and presented at the Herzen State Pedagogical University of Russia, within the Interdisciplinary Round Table «The Problem of Identity in Cultural Exclusion Zones of the Urban Environment - 2» (Saint Petersburg, 4-5 October 2019). The original argumentative line and the style of a public talk has been conserved in the present version. The author expresses his sincere thanks to Ms Vlada Koroleva, for her help in realizing the text, and to Prof. Zhanna Nikolaeva and Prof. Anna Troitskaya, for their friendly understanding and support in finalizing it. ${ }^{2}$ In this sense, the present essay could be understood as a point of development of the topic already shared with Zhanna Nikolaeva. (See: Nikolaeva \& Pirni, 2018).
} 
individual, a living creature that exists and pursues its own and specific goals related to the achievement of her individual wellbeing. It is a definition that might be easily understood as uncontroversial and universally shared.

Moreover, the second concept, urban social space, is a provisional term that I would like to introduce here. An urban social space (hereinafter: USS) is a whole of «significance»; a set of tangible and intangible social constructions that are a matter of "not-indifference" for each single agent. From here on, the normative challenge related to the interplay between agent and urban social space can start becoming clear. I'm proposing to consider and analyze here "archetypes" that have a universal, anthropological validity.

\section{THREE METHODOLOGICAL PREMISES}

In order to pursue this goal, three methodological premises are required. The first one is related to the research path mentioned at the very beginning, namely: the problem of coexisting, or the challenge of living together. In a nutshell, we could summarize that issue as the challenge of sharing of the same times and the same spaces by individuals and groups that are - and want to be recognized as - different, from an ethical, cultural and social point of view (and any other related to individual/collective forms of life), and, at the same time, as equal, from the point of view of the entitlement to the same rights (Pirni, 2018b, Ch.5,6, 8).

The current position of a person in society is devoid of unambiguity and clear certainty, which was described by Z. Bauman in the metaphors of "liquidity" (Bauman, 2000). The world requires a constant and increasingly contradictory search for identity and tracking parameters for new forms of socialization. The rationale is here the relationship and the possible modalities of interaction the self and the other (by phenomenologically reducing to this thin concept any other and more "thick" meaning of the same figure, as the alien, the visitor, the stranger, the enemy, and so on). In "The Challenge of Living Together", I proposed the relationship between the self and the other, by introducing three archetypes or three different but interrelated modalities for depicting the other. In the present context, I would like tentatively to propose an enlargement of that rationale, by including in the same schema the relationship between the self and the USS, and by considering this relationship in line of similarity with the first. As it should be clear, the basic implication is the assumed similarity between the concept of otherness and the concept of space or, in other terms, the stipulation according to which, per analogy, we are used to deal 
with the USS by putting in action the same modalities that we use for relating with another self (understood as other).

Starting from this point, we can move to the second methodological premise. Accordingly, after having recalled three typologies of otherness, we can highlight correlative typologies of interrelation with them. The forms of otherness we would like to introduce here are the following: the wall-otherness, the other-mirror-otherness and the door-otherness (Pirni, 2018b, Ch.2) ${ }^{1}$.

The first framing and model of otherness can be qualified as the wallotherness. Phenomenologically speaking, this framing of otherness precedes any other. That is to say, the Other is ascertained, at first as the edge, or as the barrier that prevents our will and our power to act. In this first modality, the other is defined as alien, dissonant, opposite. The second framing of otherness could be named as the mirror-otherness. The other is perceived first of all as someone who recognizes us because of our similarity (we mutually recognize each other). Our life pattern, value system and purposes of coexisting could be shared with this type of other. This other is a euphonic other (similar to a consonant letter) with values along similar lines to ours. The third framing and model is offered by the figure of the door-otherness, echoing what George Simmel introduced in "The Bridge and the Door" (Simmel, 1985). The door represents a radical way to distinguish, as well as to unite, it is two sides of the same coin of unity and differentiation. The Otherness of medium unification, meaning that it determines both the duality and the individuality. This contour of Otherness allows us to sum up the subtotals.

All three models of otherness enable us to address the question of identity, to answer the question "Who am I?" The first model ideally answers the question ex contrario ("I am not the other"; "I am against the other"). The second model implies a convergent type of answer, what we could call ex harmony ("I am the same as the other"). The third model provides for including the other into our group. Thus, the answer here to the question "Who am I?" is the process (I am with and through the other). The way we formulate the experience of ourselves through the procedurally, that is resembles the process of development of Hegel dialectics (thesis-antithesis-synthesis).

Starting from this comprehensive framework, we can finally approach the third methodological premise, namely, the explicit linkage of this entire rational to the perspective of USS. At this level, one can single out several

\footnotetext{
${ }^{1}$ A different but interrelated point of view is proposed in A. Pirni, Zh.V. Nikolaeva, S. Ignatieva, «Mutual Recognition: A First Philosophical Dialogue Between Italian and Russian Perspectives», (2020), forthcoming. A preliminary framing of the same issue is offered by A. Pirni (2009).
} 
basic modules, what I call intra-dynamic and extra-dynamic dimensions. The first one alludes at a permanent, namely static state of affairs. The point of departure is always the relationship between the self and the USS. The first dimension alludes to the relationship which is possible by standing and remaining within a single space: I am here, and I am moving at the same time - but without leaving that space. This implies a permanent staying and a progressive intensification of the relationship. Nonetheless, from a farther point of view, the same relationship is understood as a sort of static state of affairs: in the end, I am always in interplay with the same space. However, when we start considering the interrelation with USS, it is also necessary to insert in the comprehensive picture what I call the extradynamic dimension, that is, the intersection of several mutually different spaces, which, for the most part, are well determined and (formally or informally) enclosed. Here the reference scenario is a constant moving across spaces that are apparently open, but, in reality, reciprocally closed and independent one from another. The thing might be depicted in very simple ways. Let's conceive the daily experience related to the move from a room to another one, or from a specific building from the city center. How can I move from this room to another room, or from this building to the city center? Let's imagine the experience of going beyond a specific territory that I perfectly know, then to the city center, then to the outskirts, and then going beyond the borders of the city. We maintain as open the possibility of coming back, but the constitutive capability of moving, of constant crossing USS - not just for a journey, but also along a discrete amount of time - delivers specific effects on the single self that we are surely not so used to consider, from a social-philosophical point of view.

\section{NORMATIVE ARCHETYPES: EXCLUSION, TRANSITION, RECOGNITION - A SYNTHETIC ACCOUNT}

Now, the methodological premises above just minimally outlined may constitute a sort of theoretical framework in which insert the three modalities of crossing USS we announced at the very beginning. In stylistic accordance with the synthetic path here sketched out, in what follows we shall present just a minimal draft of a more ambitious research project which is still in draft and is waiting to be developed in details ${ }^{1}$. We shall then present three normative archetypes related to the dimension of

\footnotetext{
${ }^{1}$ I had the opportunity to present a subsequent segment of that articulation in the "Interdisciplinary Round Table "Space of the City. Identity \& Philosophy"' (Saint Petersburg State University, November 20, 2019), by delivering a paper on the topic: "The City of Limit / the Limit of the City. A Tribute to Remo Bodei". At present, a synopsis of this paper is available in: Kolesnikova, D. et al., Critical review of the materials presented in the international round table "City space: Identity and Philosophy" (2019).
} 
Crossing Urban Social Spaces (CUSS), that is: exclusion, transition, recognition.

Following the preliminary premise, we shall consider these archetypes in line of continuity with the three model of otherness we outlined above, namely the wall-otherness, the other-mirror-otherness and the doorotherness. As for the first archetype, the exclusion one, we shall assume then the preliminary reference and its intrinsic linearity with the «wallotherness»).

In this context, we will very briefly outline this concept, which is the justification for the line of succession of key studies presented by Prof. Zhanna Nikolaeva (Nikolaeva \& Pirni, 2018; Nikolaeva, 2019). In order to minimally present the overall picture in this way, we should have in mind the approaches to determining the definition of a wall-otherness, and how much they coincide with the issue jointly explored among colleagues.

Then, what is exclusion at all? Exclusion, reshaped within the conceptual vocabulary of the wall-otherness, is a cognitive and practical refusal to consider specific USS. The exception in our case is the archetypal image, it may not coincide with the social isolation that is widely understood today, and many studies have been devoted to various aspects of it. In particular, B. Barry examines economic aspect of social exclusion using the concepts of voluntary self-isolation, social justice and social solidarity (2002). There are different ways for pursuing this task. Just to list some of them, we could mention firstly the creation of cultural or physical boundaries, secondly, the creation of structural or meta-structural restrictions, and the last, but no less critical, is the implementation of the processes of ghettoization (in order to arrive to the present day gathered communities). These specifications have already been addressed in another step of our shared research project (Pirni, 2018a) ${ }^{1}$.

As for the second archetype, namely, the transition. What is transition? We have to assume first that transition is directly related to the form of otherness we called the mirror-otherness. We proceed to the last point, to the concept of punctual self, this is an essential concept in order to understand the meaning of transitivity. What is punctual for me? Punctual self, this is a complete critical immersion in myself, where I feel here. I am here; I am entirely immersed in my I, I am part of myself. I have no critical observations, considerations of what is and what surrounds me. I am just here; I just exist here in the now, I exist in me.

\footnotetext{
${ }^{1}$ Furthermore, as the history of Western civilization teaches us, this is only one of the possible modalities to contemplate the concept of "exclusion". Other and correlative in-depth research might be delivered about African and Chinese civilization, but also South America is of extreme interest about this point, from a socio-anthropological point of view. We started considering these methodological aspects with Prof. Nikolaeva.
} 
Now let's move to the third archetype, that we call recognition ${ }^{1}$. Furthermore, here you can draw a parallel with the otherness of the door. I want to introduce you to the following important point, the moment of entry and intersection of urban social spaces. You must be sure that the agent exists, that urban social spaces exist, but most importantly, that they resist. They not only exist but also provide resistance; they are not so easy to change. This is what concerns our housing, our existence, our community, changes here are problematic. It is fixed; it is defined.

According to this third and last archetype, urban social spaces are considering space and self, specifically taking into account the very idea of the single self. This assumes, of course, a historical understanding of urban social spaces, a historical understanding of the context. But also we are talking here about understanding ourselves - an individual who also contributes to the development and change of urban social spaces. Furthermore, the last characteristic is an eternal constant connection, eternal constant discrimination - permanent ongoing dialogue with the agent and urban social spaces. And then, things get more complicated. Why? Because all these archetypes work, they exist, but they do not exist in isolation from each other, they work together and simultaneously. It is necessary to imagine a world in which none of these archetypes exists in a vacuum and is not a unique driver of otherness. Here we need to go beyond the concept of duality in order to avoid an epistemological trap. That is, the proposed archetypes should not be perceived as opposites (I am against them, here against there, you need to do this, they do something, we are the coolest, and they are not so cool) and their existence will not be the only determinant of a particular phenomenon in urban space.

\section{DEALING WITH COMPLEXITY}

Let me insist on a specific point: it is necessary to avoid such duality in the interpretation of the concept, and go beyond any logic of such duality, and there any other oppositions that may arise in normative archetypes. Exception against transitivity, alienation against recognition, it is necessary to depart from all these dual categories. And still more complicated. It must be understood; it must be remembered that here we must also consider our second premise on the introdynamic and extradynamic dimensions, which I spoke about earlier. It is effortless to preserve our cognitive abilities; we can say here we have two different

\footnotetext{
${ }^{1}$ Of course, we are aware about the immense literature related to this concept. As anticipated, we can't offer even a minimal account of it in the present context. For an extended account of the specific meaning we are using in the present context, let me recall La sfida della convivenza (Pirni, 2018b, Ch. 4).
} 
modalities. One in enclosed spaces, the other modus intersection from one space to another.

Nevertheless, this is a very simplified, crystallized form of what is actually happening. Furthermore, I would like to emphasize this at the end of my essay, we need to know about the existence of alternative paths in which coexistence occurs. When there are forms of the intersection of spaces, but at the same time, there are forms of subdivision of spaces, which at the same time remain within the framework of one space. One way or another, we can exist and live in one space using the structure of alienation, transitivity and recognition. We interpret, we decide which archetype we will pay attention to, which archetypes we will consider when we exist. This is precisely what I wanted to say, we must know about their existence, we must understand that there is no simple single-valued solution, and it is impossible. Our dimension, our destiny, our destination, if it exists. In that, we understand the existence of various urban social spaces and the eternal dynamics of interaction, in which we, perhaps, have the moral right to contribute.

\section{References}

Barry, B. (2002). Social exclusion, social isolation and the distribution of income. In P. Agulnik, J. Hills, J. Le Grand \& D. Piachaud (Eds.), Understanding Social Exclusion (pp. 13-29). Oxford: Oxford University Press.

Bauman, Z. (2000). Liquid Modernity. Cambridge: Polity.

Kolesnikova, D., Nikolaeva Zh., Pirni A. \& Tsarev A. (2019). Critical review of the materials presented in the international round table "City space: Identity and Philosophy". Veche. Almanac of Russian Philosophy and Culture, 1, 214-229. (In Russian).

Nikolaeva, Zh. V. \& Pirni, A. (2018). Confini e zone di esclusione nella civiltà urbana contemporanea. Spunti per una riflessione interdisciplinare [Borders and exclusion zone in the urban contemporary civilization. Hints towards an interdisciplinary understanding], Cosmopolis. Rivista di filosofia e teoria politica, XV $(1-2)$, Retrieved

from: https://www.cosmopolisonline.it/articolo.php?numero= XV122018\&id $=14$

Nikolaeva, Zh. V. (2019). An exception as a rule. Boundaries and exclusion in the history of urban civilization. Abstracts of the conference report. Mechanisms for formation of cultural exclusion and frontier zones - 2019. Conference schedule and materials (pp. 
74-75). St. Petersburg: Sociological Institute RAS - Branch Federal Science Sociological Centre RAS.

Pirni, A. (Ed.). (2009). Logiche dell'alterità [Logics of Otherness], Pisa: ETS.

Pirni, A. (2018a). Intergenerational Dwelling: The Right to Transform, the Duty to Preserve, Studia Culturae, 37(3), 137-143. (In Russian).

Pirni, A. (2018b). La sfida della convivenza. Per un'etica interculturale [The Challenge of Living Together. Towards an intercultural ethics], Pisa: ETS.

Pirni, A., Nikolaeva, Zh. V. \& Ignatieva, S. (2020). Mutual Recognition: A

First Philosophical Dialogue Between Italian and Russian Perspectives, Vestnik of Saint-Petersburg University. Philosophy and Conflict Studies, forthcoming.

Simmel, G. (1985). Bridge and Door. Lotus International, 47. 52-56.

\section{Список литературы}

Barry, B. (2002). Social exclusion, social isolation and the distribution of income. In P. Agulnik, J. Hills, J. Le Grand \& D. Piachaud (Eds.), Understanding Social Exclusion (pp. 13-29). Oxford: Oxford University Press.

Bauman, Z. (2000). Liquid Modernity. Cambridge: Polity.

Nikolaeva, Zh. V. \& Pirni, A. (2018). Confini e zone di esclusione nella civiltà urbana contemporanea. Spunti per una riflessione interdisciplinare [Borders and exclusion zone in the urban contemporary civilization. Hints towards an interdisciplinary understanding], Cosmopolis. Rivista di filosofia e teoria politica, XV (1-2), Retrieved

from: https://www.cosmopolisonline.it/articolo.php?numero= XV122018\&id $=14$

Pirni, А. (2018a). Место обитания поколений: право на обновление и обязанность сохранения, Studia Culturae, 37(3), 137-143.

Pirni, A. (2018b). La sfida della convivenza. Per un'etica interculturale [The Challenge of Living Together. Towards an intercultural ethics], Pisa: ETS.

Pirni, A. (Ed.). (2009). Logiche dell'alterità [Logics of Otherness], Pisa: ETS.

Pirni, A., Nikolaeva, Zh. V. \& Ignatieva, S. (2020). Mutual Recognition: A First Philosophical Dialogue Between Italian and Russian Perspectives, Vestnik of Saint-Petersburg University. Philosophy and Conflict Studies, forthcoming. 
Simmel, G. (1985). Bridge and Door. Lotus International, 47. 52-56.

Колесникова, Д., Николаева Ж., Пирни, А. \& Царев, А. (2019). Критический обзор материалов, представленных на международном круглом столе «Городское пространство: идентичность и философия». Вече. Альманах Veche. Журнал русской философии и культуры, 1, 214-229.

Николаева, Ж. В. (2019). Исключение как правило. Границы и эксклюзия в истории городской цивилизации. Тезисы доклада на конференции. Механизмы формирования зон культурного отчуждения и пограничья -2019. Материаль конференции (pp. 74-75). СПб: Социологический институт РАН - Филиал Федерального научного социологического центра РАН. 